доби. Крім стандартних світильників, розташованих біля вхідних дверей і гаража, варто розмістити їх навколо будинку. Підбір освітлення має відповідати стилю будинку. Традиційні будинки добре виглядають зі світильниками, схожими на ліхтарі, які краще розташувати над вхідними дверима і гаражем. Кутове підсвічування, зазвичай, встановлюють на вході в сучасних будинках.

\title{
Література:
}

1. Лінда С. М. Архітектурне проектування громадських будівель і споруд [Текст] : навч. посіб. / С. М. Лінда; Нац. ун-т «Львів. політехніка». - 2-ге вид., випр. і допов. - Л. : Вид-во Львів. політехніки, 2013. - 642 с. : рис., табл. - Бібліогр.: с. 635-637.

2. Плоский В.О., Гетун Г.В. Архітектура будівель і споруд. Книга 2. Житлові будинки : Підручник. - Кам'янець-Подільський. : Рута, 2017 p. -736 c.

3. Дизайн екстер'єру. URL: https:/gaz.rv.ua/statti/dizayn-eksterriv/dizayn-ekster-ru/

DOI https://doi.org/10.30525/978-9934-26-172-5-23

\section{БУДІВНИЦТВО СУЧАСНИХ ЦИВІЛЬНИХ БУДИНКІВ У ЗРІЗІ ОХОРОНИ НАВКОЛИШНЬОГО ПРИРОДНОГО СЕРЕДОВИЩА}

\section{Трофимович Н. В.}

кандидат технічних наук, старший науковий співробітник,

Член-кореспондент Академії будівництва

доиент Кафедри архітектурних конструкиій

Національна академія образотворчого мистецттва і архітектури м. Київ, Україна

Перехід в будівельній галузі до нових конструктивних систем із застосуванням сучасних матеріалів і конструкцій, пришвидшення усіх стадій від проектування і будівництва інколи залишає без уваги питання збереження навколишнього середовища i, головне, здоров'я людей.

Будь-яка конструкція або конструктивна система повинні мати відповідні експлуатаційні якості, Під час обрання архітектурнопланувальних рішень виникає питання про конструктивну форму, а саме, як за умов відомих впливів, матеріалів, призначення будівлі або споруди, визначити конструктивну систему з відповідними несучими i 92 
огороджувальними елементами. Головна особливість такого визначення - це багатоваріантність рішень, що можуть бути отримані.

Розглянемо це на прикладі конструктивних систем багатоповерхових будинків (підвищеної поверховості).

Почнемо $з$ аналізу інженерно-геологічних умов у Києві. Це і зони зсувів, і просідаючі (просадні) грунти, і пливуни. Це русла рік та річок, що затиснені у підземний простір у бетонні лотки і тунелі. Наприклад, на правому березі Дніпра добре відома річка Либідь та інші притоки Дніпра, а також притоки Либіді-Піщана та інші.

Зараз вздовж проспекту Перемоги 3'явилися будинки підвищеної поверховості, що були споруджені в середині вже забудованої території, так зване, ущільненні міських територій. Дійсно, територія була знайдена, головним чином, за рахунок прибудинкової території поряд 3 п'яти-, дев'яти -поверхівками, та громадського простору і проїздів між будинками. При цьому, були зрубані дерева i кущі, вилучені прибудинкові сараї, погреби, гаражі. При цьому, ніхто не аналізував загальне навантаження н грунти у вказаних місцях.

Відомо, що, коли під верхніми шарами грунту, на глибині декількох метрів знаходиться горизонт підземних вод, то при привантаженні грунтів поряд, цей рівень піднімається за рахунок витиснення води(відомий з фізики закон Паскаля), особливо, коли навкруги буронабивні пальові фундаменти довжиною 30-35 метрів. Підтоплюються підвали поряд розташованих будинків, підземні переходи. Дощова каналізація з цим не може впоратися під час рясних дощів.

Питанню щільної забудови в межах існуючих мікрорайонів міст присвячено статтю автора 11 , де висвітлене питання руйнування сусідніх будинків поряд 3 новим будівництвом житлово-офісного будинку підвищеної поверховості, внаслідок технічної неможливості дотриматися діючих нормативних документів у галузі будівництва України. Додатково звертаю увагу на зовсім не врахований, під час проектування і будівництва у затисненій міській забудові об'єктів підвищеної поверховості, вплив вітру внаслідок зміни напрямку повітряних потоків, які збільшують свою інтенсивність, майже до явищ «флатера». 3'являється відсмоктування або додатковий натиск вітрового потоку, що, фактично, руйнує дах будинків, що розташовані поряд, мають висоту у три рази менше, ніж у нового об'єкту.

Сучасний стан в Україні, що пов'язаний 3 ринком енергоносіїв, високою вартістю природного газу, якого у нас, нашого видобутку, не вистачає у достатній кількості, для задоволення усіх потреб, як у житлово-комунальному господарстві, так і у промисловості, викликає питання енергозбереження в усіх галузях. 
Нагадаю, що в Україні, більше, ніж 20 років тому. В будівельній галузі було розроблено, затверджено і впроваджується галузеву програму енергозбереження у житловому та громадському будівництві, введено і і впроваджуються нові підвищені, майже, у два рази теплотехнічні нормативи для стін і вікон, до розробки, затвердження i впровадження нових технічних рішень огороджувальних конструкцій 3 підвищеними теплотехнічними властивостями, залучено науководослідні проектні і будівельні організації. При цьому, широко впроваджуються нові рішення інженерних систем опалення та водопостачання. Зараз налагоджений облік усіх видів енергоресурсів, тепло-і водопостачання.

На мою думку, тепер можна проаналізувати деякі наслідки впровадження енергозберігаючих конструктивних рішень та інженерного обладнання у житлових і громадських будинках. Зупинюсь, виключно, на технічних проблемах, які потребують додаткового вивчення, аналізу та дослідних перевірок на предмет збереження, чи ні, експлуатаційних показників, згідно до затвердженої проектно-кошторисної документації, а також, на питаннях безпеки перебування людей у таких утеплених будинках, як нового спорудження, так і існуючої забудови, що була запроектована і споруджена за зменшених нормативних вимог щодо енергозбереження, орієнтовно, на $30 \%$.

Однією з проблем є неоднакова довговічність системи утеплення, в порівнянні 3 несучою або самонесучою конструкцією стіни, яка різниться, майже, на порядок. Звідти, непрогнозована тривалість експлуатації усіх компонентів системи утеплення з забезпеченням постійних показників комфортності проживання. На перший погляд, пройшло не так вже і багато часу. При цьому, у технічних умовах на ефективні матеріали утеплювачів та метало-пластикові вікна надано інформацію, що вказані елементи можуть зберігати свої властивості 2050 років. В той же час, хімічні особливості вказаних матеріалів, що знаходяться під дією атмосферних впливів, а не в лабораторних умовах зі сталими показниками температури і вологості, ультрафіолетового та інфрачервоного випромінювання, наводять на інші думки. Полімерні зв'язки з часом руйнуються в природному середовищі. Це стосується енергоефективних утеплювачів. I пінополістирольні утеплювачі, i пінополістирольна опалубка, що не знімається, і вікна із застосуванням пластичних матеріалів. Також не можуть бути задекларованої довговічності жорсткі мінерально- та скло- волокнисті плити, де в якості просочування для надання жорсткості також використовуються синтетичні речовини. 
Несуча конструкція стіни, як правило, виготовляється із залізобетону, дрібних та великих штучних та природних каменів, цегли, довговічність яких вимірюється, приблизно, у 100 років. Утеплювач, як правило, із мінерально- або скло-волокнистих жорстких плит чи пінополістиролу, які, безумовно не будуть існувати стільки ж років, як і несучі конструкції. Крім цього, наявність полімерних матеріалів у складі огороджувальних конструкцій, потребує аналізу питання виділення шкідливих речовин під час руйнування полімерних зв'язків у повітря. Треба не забувати про сучасні меблі, що виготовляються із пресованих деревостружкових плит із застосуванням синтетичного просочувача, що також потрапляє у повітря. Необхідно поставити питання перед виробниками продукції про надання інтегрального показника випромінювання у повітря шкідливих речовин під час експлуатації меблів та утеплювачів, пластикових вікон та матеріалів оздоблення. Показник, безумовно, буде змінюватись у часі, в бік зменшення, наприклад, у меблях, що експлуатуються у постійному, з точки зору, вологості і температури, середовищі, та у бік збільшення, в утеплювачах та пластикових вікнах, за рахунок атмосферних впливів та старіння пластичних мас.

Утеплення із ніздрюватих бетонів малої густини тільки 3 середини приміщення поширене зараз у багатоповерхових будинках. Для забезпечення сталих фізико-механічних властивостей таких утеплювачів, необхідно іх захищати від зволожування шляхом нанесення 3 середини приміщення водонепроникних плівок та водонепроникних захисних розчинів. Температурно-вологісний режим приміщень, у такому випадку, потребує окремої уваги щодо забезпечення комфортних умов проживання. У такому приміщенні, особливо, в опалювальний період, занадто сухе повітря.

Зараз за вказаними технологіями споруджена велика кількість будинків, чимало будинків старої забудови відновлено за підвищеними теплотехнічними вимогами, які вже не один рік споживають теплову, електричну енергію, і можуть надати відомості щодо рівня інженерного забезпечення будинку, економії витрат, а також комфортних умов проживання. Можливо зібрати відомості також 3 відповідних організацій, що забезпечують обслуговування будинків $з$ підвищеними теплотехнічними показниками.

Також необхідно розглянути стан зовнішніх стін із застосуванням утеплення та провести необхідне технічне обстеження у випадках аварій (відсутність опалення, пориви мереж тепло - водопостачання)

Проблемою $є$ також відсутність достатнього досвіду при ремонті та заміні утеплювача зовнішніх стін, у разі потреби. Зараз відсутні технічні 
рішення щодо заміни навісних вентильованих та мокрих фасадів у будинках вище 18 поверхів. Окремі ділянки ремонтуються, а відновлення повністю технічною документацією досі не забезпечене.

Питання виникає і у випадку внутрішнього утеплення пінополістиролом та при використанні пінополістирольної опалубки, що не знімається при псуванні пінополістиролу у випадку пожежі. Несуча конструкція-залізобетон залишився, майже, без змін, пінополістирол підпав під термодеструкцію, перетворився на інші матеріали і зник повністю або частково. Доцільно вказані питання ввести у нормативні документи з питань реконструкції та ремонтів.

Не останнє питання - це пожежна безпека висотного будинку. Без примусових вентиляторів, які повинні включатись при загорянні i відводити шкідливі продукти загоряння від житлових приміщень. На жаль, таких вентиляторів у великій кількості будинків немає. Покриття важкогорючими та полімерними матеріалами при оздобленні зовнішніх i внутрішніх стін будинків також може призвести при загорянні до отруєння людей чадним газом. Наскільки, мені відомо, термодеструкція полімерних матеріалів призводить до виділення у повітря отруйних речовин.

Додатково звертаю увагу на те, що підвищення щільності забудови без спорудження відповідної інфраструктури інженерних мереж, включаючи автомобільні шляхи, які призначені для під'їзду усіх видів рятувальної техніки, може привести до важких техногенних аварій i катастроф.

Досвід спорудження багатоповерхівок у центрі Києва показав, що суттєво погіршився стан інженерного забезпечення у місцях щільної забудови. Це відбулося внаслідок перенавантаження електричних, теплових та водопостачальних мереж. Також неможливо розширити у достатній мірі автошляхи у затиснених міських територіях. Тобто додатково маємо коло кожної такої багатоповерхівки автомобільний корок із власних автомобілів. Фактично утворити необхідні за обсягом транспортні розв'язки у центрі та прилеглих до центра районів неможливо, якщо не знести близько $30-50 \% \%$ існуючої забудови та, майже, усі зелені насадження-легені міста.

Якщо звертати увагу на закордонний досвід та приводити приклади забудови висотними будинками країн Свропи, то одразу впадає в око, як обережно це робиться у містах, що мають тисячолітню історію, як i наш Київ. Там забудовують, головним чином, околиці, де вирішується питання прокладання нових сучасних інженерних мереж та транспортних розв'язок. 
Останні роки в Києві теж відбувається забудова околиць. При цьому, враховуються усі технічні можливості району.

\section{Література:}

1. Трофимович Н.В. Пропозиції щодо проектування та будівництва житлових будинків у складних інженерно-геологічних умовах у міській забудові. International scientific and practical conference "Science, engineering and technologies: current issues and research", March 12-13, 2021, Czech Technical University in Prague, Czech Republic. C. $197-202$ 